\title{
フタロシアニン電界発光素子における $\mathrm{NO}_{2}$ ガス吸着に伴う 電気伝導および発光特性の変化
}

\author{
正員 新保一成(新潟大) 非会員 皆川正寛(新渴大) \\ 非会員 高坂 秀 明 (新潟大) 正員 加藤 景三(新潟大) \\ 正員金子双男 (新酎大)
}

Conduction and Luminescent Properties Due to $\mathrm{NO}_{2}$ gas Adsorption

in Phthalocyanine Electroluminescent Device.

Kazunari Shinbo, Member, Masahiro Minagawa, Non-member, Hideaki Takasaka, Non-member,

Keizo Kato, Member, Futao Kaneko, Member (Niigata University)

\begin{abstract}
Electroluminescent (EL) devices of metal-free phthalocyanine $\left(\mathrm{H}_{2} \mathrm{Pc}\right)$ were fabricated and electrical and luminescent properties due to $\mathrm{NO}_{2}$ gas adsorption were investigated. The device had an ITO bottom electrode (anode)/ $\mathrm{H}_{2} \mathrm{Pc}$ $(100 \mathrm{~nm}) / \mathrm{Al}$ top electrode (cathode) structure. The Al films were deposited using an oblique deposition method in order to obtain porous structure to enable $\mathrm{NO}_{2}$ gas adsorption into the $\mathrm{H}_{2} \mathrm{Pc}$ layer through the $\mathrm{Al}$ film. The conduction currents and the EL intensities of the device increased with $\mathrm{NO}_{2}$ gas adsorption. Open-circuit voltage generations due to irradiation of monochromatic light at $730 \mathrm{~nm}$ and/or due to $\mathrm{NO}_{2}$ gas adsorption were also observed. It was estimated that the adsorbed $\mathrm{NO}_{2}$ gas in $\mathrm{H}_{2} \mathrm{Pc}$ captured negative electrons at the Schottky barrier of the $\mathrm{H}_{2} \mathrm{Pc} / \mathrm{Al}$ interface. It was thought that the increase in the conduction currents and EL intensities due to the gas adsorption was caused by the modification of the depletion layer, and that efficient injection and recombination of carriers due to the $\mathrm{NO}_{2}$ gas adsorption produced the increase in the EL intensities.
\end{abstract}

キーワード: フタロシアニン 有機電界発光素子 $\mathrm{NO}_{2}$ ガス 開放端電圧 センサ

keywords: phthalocyanine, organic electroluminescence device, $\mathrm{NO}_{2}$ gas, open circuit voltage, sensor

\section{1.まえがき}

フタロシアニン $(\mathrm{P}$ c $)$ 注、高い耐光性・耐熱性を示す 有機色素半導体の一種である。その光・電子機能は結晶形 や中心金属により制御可能であり、種々の誘導体が合成さ れ、幅広い分野で盛んに研究が進められている(1)。P C は 多くの機能性を有しており、非線形光学効果やエレクトロ クロミズムを示すことで知られている他、有機太陽電池や 光記録媒体八の応用等も検討されている(2)-(5)。また、P C は一般にp形伝導を示すが、ここに電子供与性または受容 性のガスが吸着するとキャリヤ数と導電率が増減する。こ れを用いて、主に $\mathrm{NO}_{2}$ ガスセンサへの応用に関する研究 が多く報告されてきている(6),(7)。

また、近年有機電界発光 $(E L)$ 素子に関する研究が盛 んに行われているが、P C は I T O陽極と正孔輸送層の間 のバッファ層として有用であることが知られている(8)(9)。 これは、P Cのイオン化ポテンシャルが、I TO電極の仕 事関数と、正孔輸送層のイオン化ポテンシャルの中間に位 置し、正孔が注入されやすくなること等によると考えられ ている。また、P C を発光湄しした研究も報告されており、
無金属フタロシアニン $\left(\mathrm{H}_{2} \mathrm{P} \mathrm{c}\right)$ では青色領域上近赤外領 域に分離した発光を示すことが知られている(10)。

本研究では、このような P c の機能に着目し、 $\mathrm{H}_{2} \mathrm{P} \mathrm{c}$ を発光層とする単層型有機 $\mathrm{E} \mathrm{L}$ 素子を作製すると共に、 $N$ $\mathrm{O}_{2}$ ガス吸着に伴う電気伝導と発光特性の変化について調 ベた。特に、ガス吸着による電導電流と発光強度や発光効 率の変化、また開放端電压の発生等を検討した。このよう なガス吸着に伴う電気特性や発光特性の変化はこれまで あまり調べられておらず(11)、本研究の結果は素子特性の制 御やセンシングデバイス等への応用に有用と考えられる。

\section{2. 試料の作製と実験方法}

図 1 と図 2 に、そ扎ぞれ本研究で使用した無金属フタロ シアニン (東京化成株)、 $\mathrm{H}_{2} \mathrm{P} \mathrm{c}$ ) の構造と光吸収特性を示 す。図 2 における紫外域、可視域の吸収はそれぞれBバン ド、Qバンドによるものと考えられる(10)。作製した E L 素子は、下部 I T O陽極 $/ \mathrm{H}_{2} \mathrm{P} \mathrm{c}$ (膜厚 $100 \mathrm{~nm}$ ) ／上部 A 1 電極 (面積 $10 \mathrm{~mm}^{2}$ ) の構造とした。 $\mathrm{H}_{2} \mathrm{P} \mathrm{c}$ はp 形伝 遒を示すので、I T O電極と $\mathrm{H}_{2} \mathrm{P}$ c の界面ではオーム接 触、 $\mathrm{Al}$ 電楆と $\mathrm{H}_{2} \mathrm{P}$ c の界面ではショットキ一接触とな 
る(12,13)。電流電圧特性は、I T O電極に正電圧を印加する 場合を順方向として測定を行った。上部A 1 電極は斜方蒸 着法により作製した。蒸着源と基板法線のなす角（基板傾 斜角 $\theta$ ) を大きくすることで、自己陰影効果により表面凹 凸や小孔の多い薄膜を得ることができる(14),(15)。これによ り $\mathrm{H}_{2} \mathrm{P} \mathrm{c}$ 層へのガス吸着を行わせることを試みた。なお、 作製したA 1 薄膜表面を、原子間力顕微鏡（AFM，米国 Digital instruments(侏)）を用いて観察した。

電気特性と発光スペクトルの測定は、作製した E L 素子 をチャンバー内に保持し、0.01Torr の真空中、または $\mathrm{N}_{2}$ 中 $100 \mathrm{ppm}$ の $\mathrm{NO}_{2}$ ガスを流入させて、それぞれエレクト ロメータ（Keithley、6517）とマルチチャネルホトディテ ク夕（大塚電子(株)、IMUC-7000）を用いて行った。

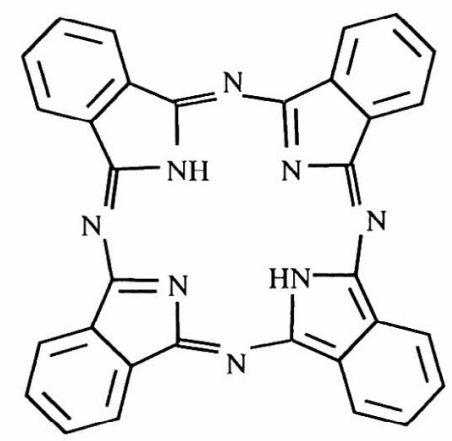

図 1 本研究で用いた無金属フタロシアニンの分子構造

Fig.1. Chemical structure of metal-free phthalocyanine used in this work.

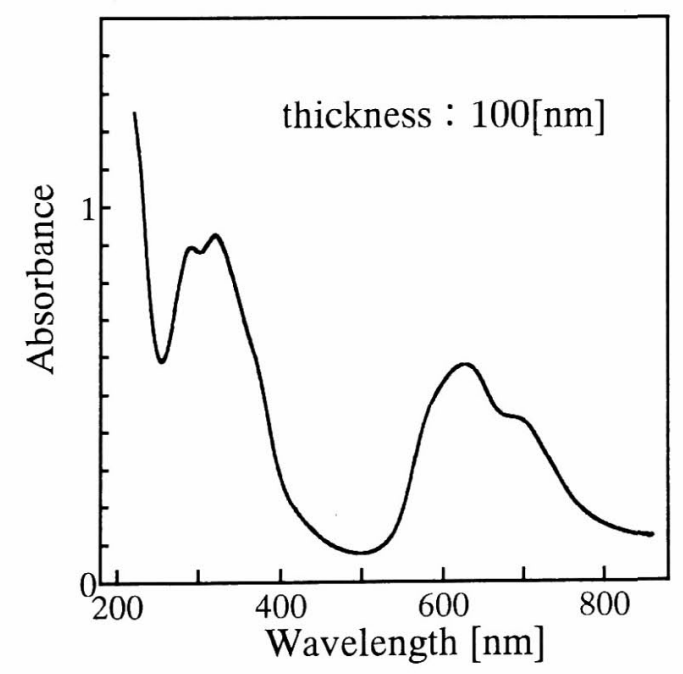

図 $2 \mathrm{H}_{2} \mathrm{P}$ c 薄膜の光吸収スペクトル

Fig.2. Optical absorption spectrum of the $\mathrm{H}_{2} \mathrm{Pc}$ Film.

\section{3. 実験結果と考察}

$\langle 3 \cdot 1\rangle$ A I 薄膜のAFM像図 3(a),(b)に、それ ぞれ平面蒸着（基板傾斜角 $\theta=0^{\circ}$ ） および斜方蒸着（ $\theta$ $=70^{\circ}$ ）で作製したA 1 薄膜表面のA F M像を示す。斜方 蒸着により、明らかに表面凹凸が大きくなっていることが わかる。このような薄膜を電極として用い、 $\mathrm{NO}_{2}$ 中にお ける電気特性と発光特性を測定した。なお、図(b)のよう な斜方蒸着したA 1 電極を用いた素子でのみガス吸着に 対する明確な応答が観測された。

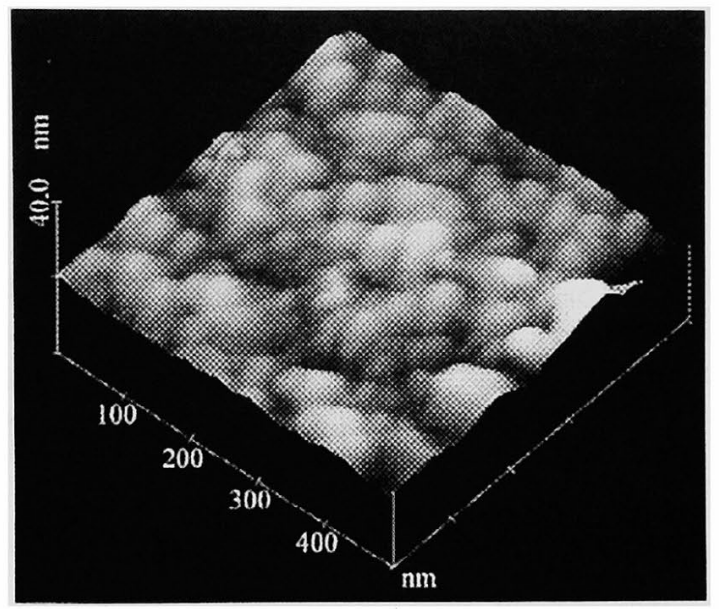

(a) 平面蒸着 $\left(\theta=0^{\circ}\right)$

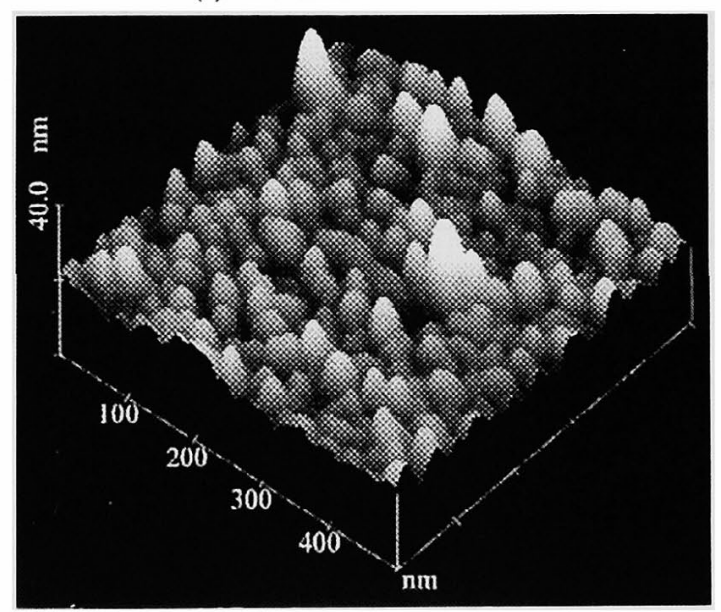

(b) 斜方蒸着 $\left(\theta=70^{\circ}\right)$

図 3 A 1 薄膜の A F M 像

Fig.3. AFM images of the Al films evaporated (a) at $\theta=0^{\circ}$ and (b) $\theta=70^{\circ}$

く3. 2 > $\mathrm{NO}_{2}$ ガス吸着による電気特性の変化 図 4 に、I T O電極への印加電圧を $9 \mathrm{~V}$ 一定とし、 $\mathrm{NO}_{2}$ カj ス吸着による電導電流の変化を測定した結果を示す。あら かじめチャンバー内は 0.01Torr まで排気し、その後 30Torr までガスを流入させて時間変化を観測した。ガス流入に伴 って、電流值は大きく増加していることがわかる。これに 対して、ガス流入を遮断して排気を行うことにより、電流 值は減少した。このようなガス流入による電流值の変化は、 可逆的に観測された。

図 5 は、真空 0.01Torr, $\mathrm{NO}_{2}$ ガス 1Torr および 30Torr 中において測定した電流電圧特性を示したものである。順 方向について、縦軸に電流值の対数、横軸に印加電界の平 方根を取って示すと、プロットは比例関係となった。伝導 機構として次の(1), (2)式に示されるようなショットキー 伝導かプールフレンケル伝導を考えた場合、静電容量を用 
いて計算した比誘電率から、式中の $\beta_{\mathrm{S}}$ と $\beta_{\mathrm{PF}}$ は(3)式のよ うに求められた。

Schottky Conduction: $\quad \mathrm{I} \propto \exp \frac{\beta_{\mathrm{S}} \sqrt{\mathrm{E}}}{\mathrm{kT}}$

Poole-Frenkel Conduction: $\quad \mathrm{I} \propto \exp \frac{\beta_{\mathrm{PF}} \sqrt{\mathrm{E}}}{2 \mathrm{kT}}$

$$
\beta_{\mathrm{PF}}=2 \beta_{\mathrm{S}}=\sqrt{\frac{\mathrm{e}^{3}}{\pi \varepsilon}}=8.28 \times 10^{-24}
$$

これに対して、電流電圧特性の直線の傾きから得られた $\beta$ の実験值を、表 1 に示した。真空中ではショットキ一伝導、 ガス吸着後はプールフレンケル伝導に近いという結果に なった。図 4 や図 5 のよな伝導特性の変化については、 く3．5>節において詳しく教察する。

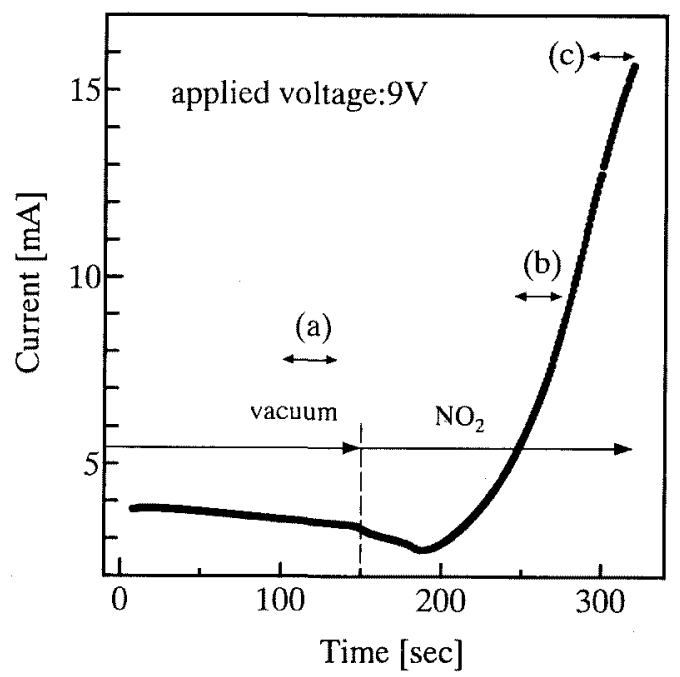

図 4 ガス吸着前後における電導電流

Fig.4. Conduction current at $9 \mathrm{~V}$ before and after flowing $\mathrm{NO}_{2}$ gas.

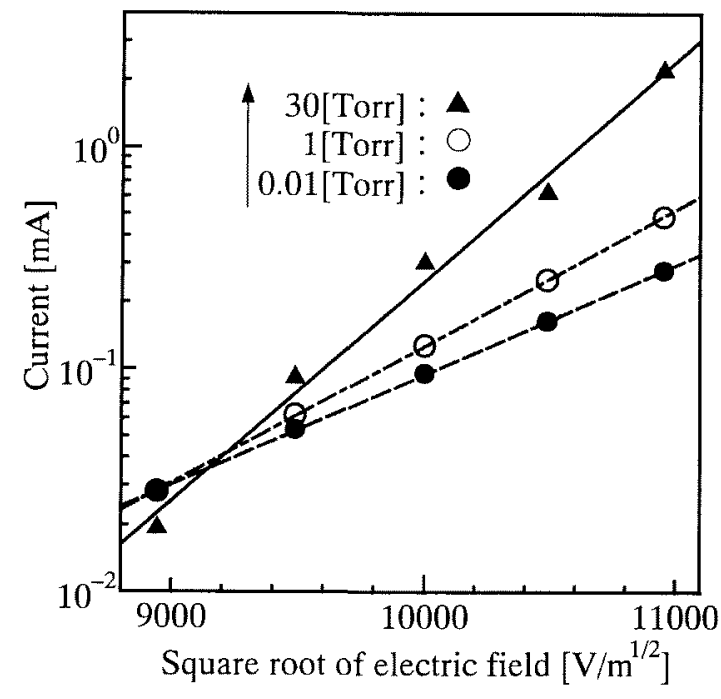

図 5 種々の雾囲気下における電流電压特性

Fig.5. Conduction current vs. electric field properties under various atmospheres.
表 1 電界発光素子における $\beta$ の実験值と理論值 Table 1. Experimental and theoretical $\beta$ of the conduction vs, electric field properties for the $\mathrm{H}_{2} \mathrm{Pc}$ EL device.

\begin{tabular}{|l|l|}
\hline Theoretical value & Experimental value \\
\hline$\beta_{\mathrm{PF}}=8.28 \times 10^{-24}$ & 30Torr: $9.24 \times 10^{-24}$ \\
$\beta_{\mathrm{S}}=4.14 \times 10^{-24}$ & 1Torr: $5.76 \times 10^{-24}$ \\
& 0.01Torr: $4.63 \times 10^{-24}$ \\
\hline
\end{tabular}

く3.3> $\mathrm{NO}_{2}$ ガス吸着による電界発光特性の変化 図 4 から、ガス吸着と共に電流值が增大することを述べた が、図 4中の領域(a)〜 (c)におけるELスペクトルを測定 した結果を図 6 に示す。図中に各スペクトル測定時の電流 值も示した。電流の增大と共に、 $\mathrm{E} L$ 強度も大きくなうて いる。すなわち、ガス吸着により E L 特性が変化すること がわかった。なお、E L特性についても、ガス吸着と脱着 に伴う強度の增減が可逆的に観測された。また、500 $\mathrm{nm}$ と $780 \mathrm{~nm}$ 以上の領域に発光が見られているが、これらはそれ ぞれ BバンドとQバンドに対応するものであると考えら れる。なお、波長 $780 \mathrm{~nm}$ 以上については、今回使用した 測定装置の特性のため測定できなかった。

次に、電導電流を $1 \mathrm{~mA} / \mathrm{mm}^{2}$ 一定とし、真空中及び $\mathrm{N}$ $\mathrm{O}_{2}$ ガス中におけるE L 特性を測定した結果を図 7 に示す。 電流值が一定であるにも関わらず、 $\mathrm{E} L$ 強度が大きくなっ ていることがわかる。このような発光効薪の向上について は明確ではないが、ガス昅着によりキャりヤ注入のバラン スや発光過程に何らかの変化が生じたためと考えられる。 なお、 $\mathrm{NO}_{2}$ ガスの吸着による素子の劣化も観測されるが、 詳細はまだ明らかになっておらず、今後調べていく予定で ある。

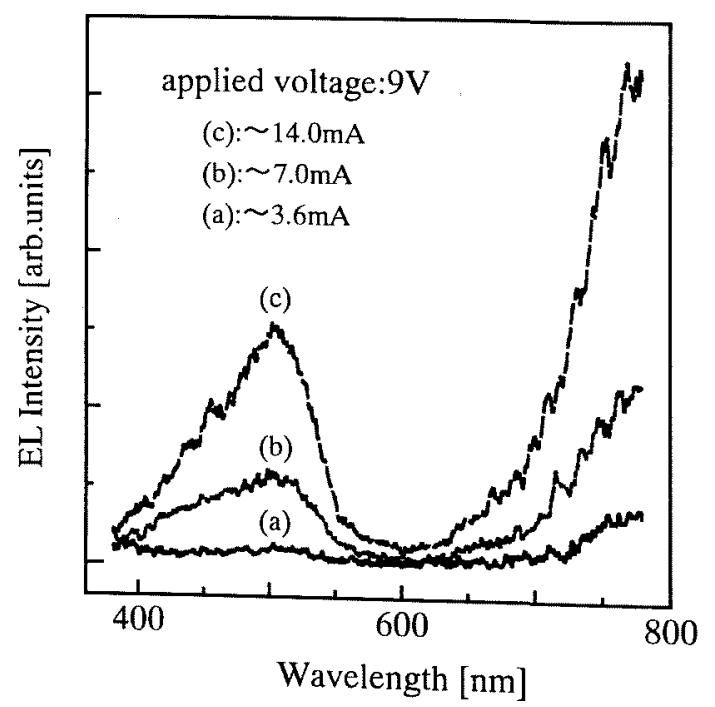

図 6 種々の需囲気下における E L スペクトル(印加 電压 $9 \mathrm{~V}$ 一定)

Fig.6. EL spectra at $9 \mathrm{~V}$ under various atmospheres. 


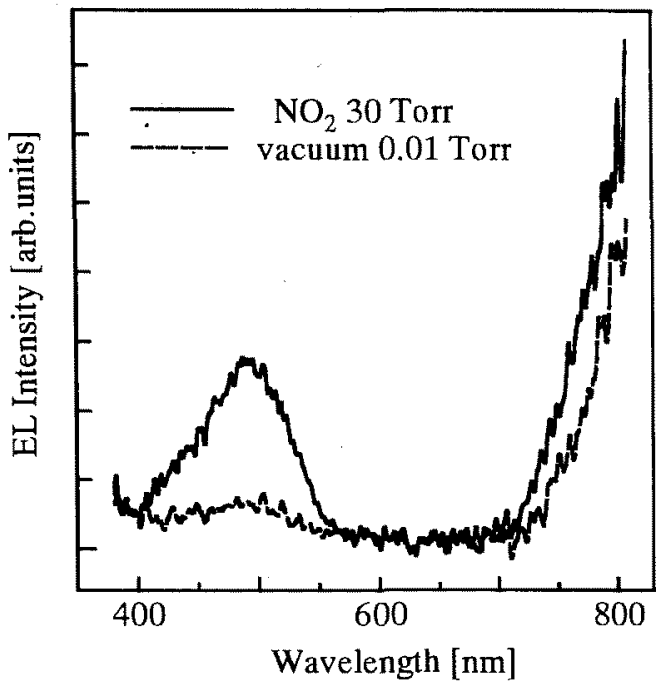

図 7 電流密度 $1 \mathrm{~mA} / \mathrm{mm}^{2}$ における真空中または $\mathrm{NO}_{2}$ ガス中での $\mathrm{E} \mathrm{L}$ 特性

Fig.7. EL spectra at a constant conduction current density of $1 \mathrm{~mA} / \mathrm{mm}^{2}$ in vacuum and $\mathrm{NO}_{2}$ atmosphere.

く3.4> ガス吸着による開放端電圧の発生フタロ シアニンは顕著な光起電効果を示すことが知られている。 本研究においても、作製した有機 EL素子に刘して、ガス 吸着および光照射による開放端電圧々短絡光電流の測定 を行った。照射光は、予め0.01Torr の真空中で測定した短 絡光電流の照射光波長依存性において、ピ一クが観測され た波長 730nm の篻色光を用いた。

図8に測定結果を示す。0.01Torr の真空中および 30Torr の $\mathrm{NO}_{2}$ 中において光照射したところ、I TO電極正之 する開放端電圧が観測された。次に、光を遮断してN $\mathrm{N}_{2}$

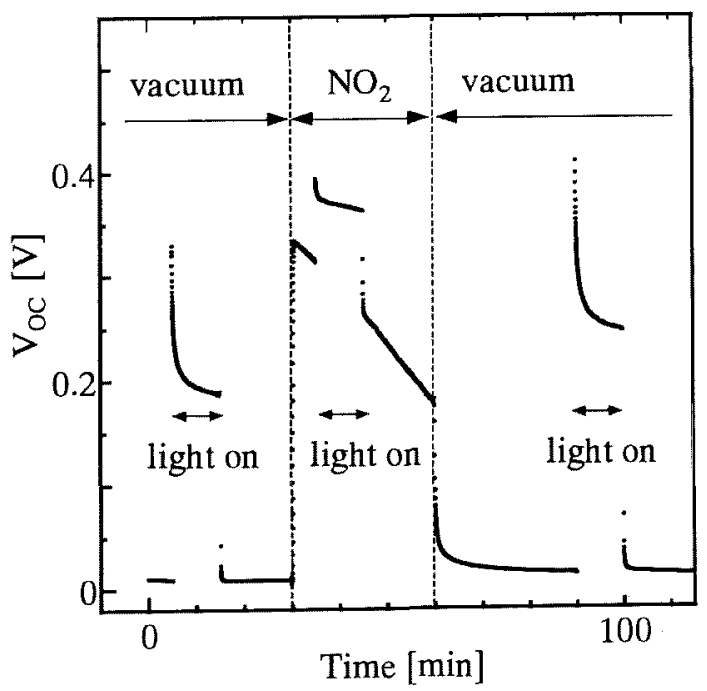

図 8 光照射およびガス吸着による 開放端電圧の発生

Fig.8. Open circuit voltage due to light irradiation and $\mathrm{NO}_{2}$ gas adsorption.

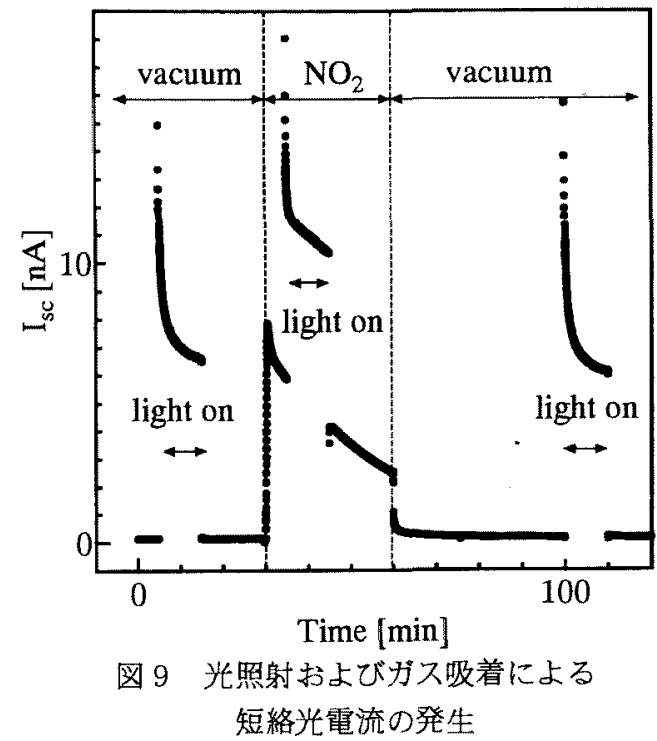

Fig.9. Short circuit current due to light irradiation and/or $\mathrm{NO}_{2}$ gas adsorption.

ガスを流入する上、暗中にもかかわらず同じ極性の電圧発 生が観測された。この状態で光照射すると、さらに電圧が 大きくなることがわかつた。同様に短絡光電流について測 定を行った結果を図 9 に示す。光照射とガス吸着に対して、 四 8 とほぼ同様の㐫答が観測された。

これに対して、下部 I T O陽極 $/ \mathrm{H}_{2} \mathrm{P} \mathrm{C}$ （膜厚 100nm） ノ上部A u電極とした素子を作製し、開放端電圧の測定を 行った。この結果を図 10 に示す。本素子では、 $\mathrm{H}_{2} \mathrm{P} \mathrm{c}$ と I T O 、 $\mathrm{H}_{2} \mathrm{P}$ C と A u両界面が才一公接触となってい

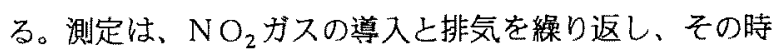

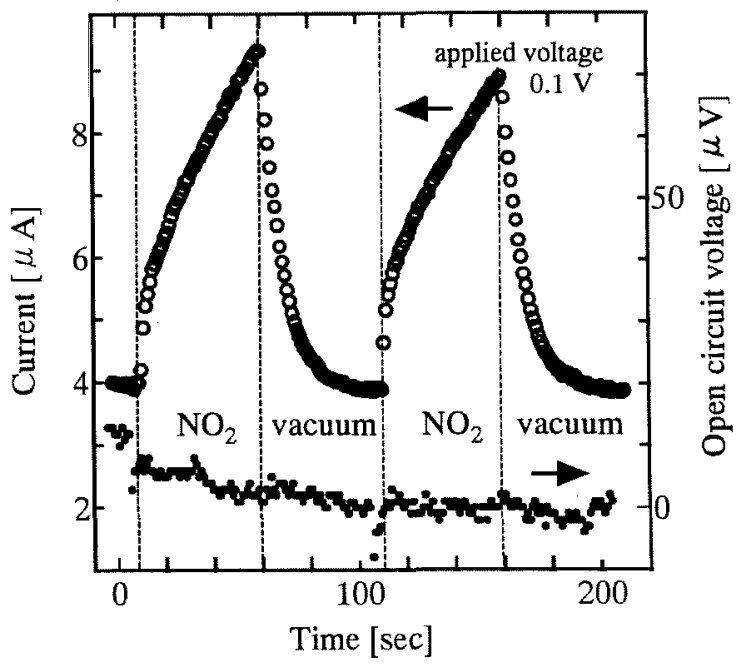

図 $10 \quad \mathrm{NO}_{2}$ ガス吸着による電導電流および開放端 電圧の変化 ( $\mathrm{I} \mathrm{T} \mathrm{O} / \mathrm{H}_{2} \mathrm{P} \mathrm{c} / \mathrm{Au}$ u素子)

Fig. 10. Change of conduction current and open circuit voltage due to influx and exhaust of $\mathrm{NO}_{2}$ gas for an $\mathrm{ITO} / \mathrm{H}_{2} \mathrm{Pc} / \mathrm{Au}$ device. 
の電流と電圧応答を観測している。電流測定における印加 電圧は $0.1 \mathrm{~V}$ である。図 10 において、電導電流はガス流 入により変化しており、素子が $\mathrm{NO}_{2}$ ガスに対して応答し ていることがわかる。しかし、開放端電圧の変化量は非常 に小さかった。これは、開放端電圧の発生に電極金属が大 きく関係していることを示している。

<3，5> バンド構造の概略とガス応答機構 以上の ような、 $\mathrm{NO}_{2}$ ガス吸着に伴う電導電流や E L 強度の増大、 電流電圧特性の変化、開放端電圧の発生について考察する。 まず、本素子のバンド構造の概略は図１１のようになっ

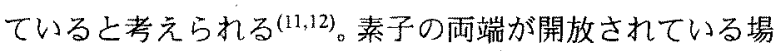
合を考える。前述したように $\mathrm{H}_{2} \mathrm{P}$ c は $\mathrm{p}$ 形伝導を示すた め、上部AＩ電極とはショットキー接触となり、空間電荷 (空乏) 層が形成されていると推察される。ここに上部電 極を通して電子受容性の $\mathrm{NO}_{2}$ ガスが吸着すると、 $\mathrm{H}_{2} \mathrm{P} \mathrm{C}$ から電子を奪うことによってガス分子は負に帯電し、また 膜中には正孔が発生する。この正孔は空間電荷層中の電界 に治ってドリフトし、I T O側へ移動する。これに対して、 電子を临って負電荷を持った $\mathrm{NO}_{2}$ ガスは $\mathrm{Al}$ 電極との界 面付近に蓄積すると思われる。このようにして発生する 正・負電荷の偏りによって、I T O 側に正の開放端電圧を 発生させると考えられる。また、素子両端が短絡されてい る場合は、同様の現象によって外部回路を I T O 側から A 1 側八電流が流れ、同時に負に帯電した $\mathrm{NO}_{2}$ ガスの存在 により空之層幅は小さくなる。

図 60 電流電压特性のプロットの傾さは、真空中ではシ ヨットキー伝導、ガス吸着後はプールフレンケル伝導に近 いよいう結果が得られている。明確ではないが、このよう な変化はガス吸着に伴う高抵抗の空乏層幅の減少に基づ くトンネル効果や、またはガス吸着に伴いキャリヤの移動 サイトとなる準位が形成される等により、A 1 と $\mathrm{H}_{2} \mathrm{PCC}$ 界面における障壁の影響が小さくなったことに起因する ものと考えられる。すなわち、ガス吸着後は空乏層の寄与 が小さくなるのでバルク制限であるプールフレンケル効 果が観察されたと推祭される。さらに、 $\mathrm{NO}_{2}$ ガス吸着に 伴い発生した正孔による抵抗率の低下などにより、電導電 流および $\mathrm{E} L$ 強度が增大するものと考えている。また、真 空中においてショットキー伀導に近くなったのは、空乏層 の部分に電界が集中することによってプールフレンケル 伝導を示す $\mathrm{H}_{2} \mathrm{P}$ c の中性領域にかかる電界が小さくなり、 見かけ上傾さが小さくなったためではないかと推察され る。ただし、本素子においては他の伝導機構が複合してい る可能性も考えられるため、今後さらに検討が必要である。 なお、図 8 において $\mathrm{NO}_{2}$ ガスにより発生した開放端電圧 は、時間と共に大きく減衰している。これは、 $\mathrm{NO}_{2}$ ガス 吸着が飽和し始め、正孔の発生が減少することと、I TO 電極に蓄積した電荷が測定回路を通して消失すること等 に基づくものと考えられる。図 9 の $\mathrm{NO}_{2}$ ガス吸着による 短絡電流の減衰も、同様に吸着の飽和によると思われる。 しかし、負に帯電した吸着 $\mathrm{NO}_{2}$ ガスは素子中にとどまる
ため、ここに述べたような空乏層や電流電圧特性の変化を 引き起こしているものと考える。

また、図8のようにガス吸着時に発光効率が向上する理 由については前述したようにまだ明らかではないが、ガス 吸着によりA１電極からの電子注入量が増大する、発光プ ロセスになんらかの変化が生じるなどのことが考えられ る。

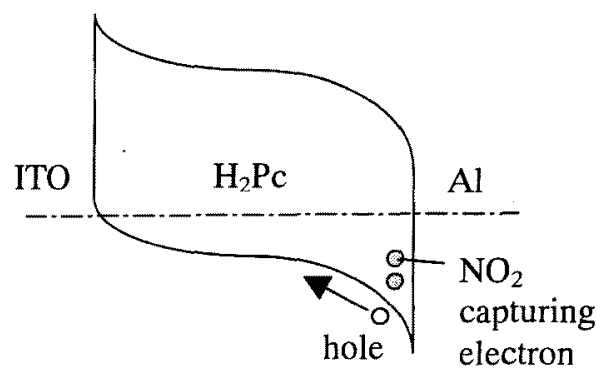

Just after exposure to $\mathrm{NO}_{2}$ gas.

$\downarrow$

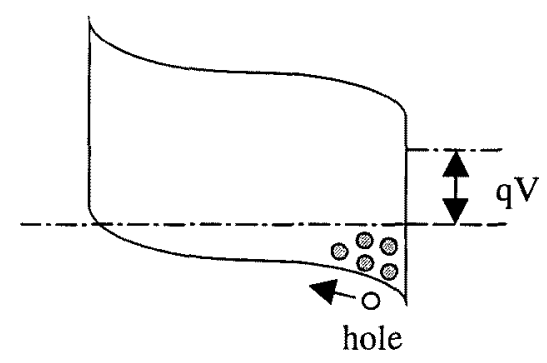

Voltage generation due to $\mathrm{NO}_{2}$ adsorption.

図 11 ガス吸着によるエネルギー帯図のモデル

Fig.11. A model of the energy band due to $\mathrm{NO}_{2}$ gas adsorption.

\section{4.まとめ}

無金属フタロシアニン $\left(\mathrm{H}_{2} \mathrm{P} \mathrm{c}\right)$ を発光層とする有機 電界発光素子を作製し、 $\mathrm{NO}_{2}$ ガス吸着に伴う電気特性、 発光特性の変化について調べた。 $\mathrm{NO}_{2}$ ガスの吸着と脱離 により電尊電流と $\mathrm{EL}$ 強度は增減し、可逆性が見られた。 これは、吸着した $\mathrm{NO}_{2}$ ガスが $\mathrm{H}_{2} \mathrm{PC}$ ○ら電子を奪って負 イオン化し空乏層幅を変えることや、ガス吸着により生じ る準位の寄与などにより、 $\mathrm{H}_{2} \mathrm{P}$ C とA 1 界面の影響が小 さくなること、またガス吸着によって発生する正孔による 抵抗率の低下等のため、電流が流れやすくなることが原因 と考えられた。さらに、ガス吸着による開放端電圧や短絡 電流の発生も観测された。これは、 $\mathrm{H}_{2} \mathrm{P}$ c とA 1 界面の 空乏層付近で発生した正孔が内蔵電界に治って I T O電 極側へ移動することに基づくと推察された。

本研究の結果は、有機 E L素子の発光特性の制御や、セ ンシングデバイスなどの構築に役立つものと考えられる。

(平成 12 年 9 月 27 日受付、平成 13 年 3 月 5 日再受付)

本研究の一部は、文部省科研費の補助による。 


\section{文献}

(1) 白井・小林 :「フタロシアニンー化学と機能一」アイ ピーシー, 1997

(2) T.Wakamatsu, K.Saito, Y.Sakakibara, H.Yokoyama: "Enhanced Photocurrent in Organic Photoelectric Cells Based on Surface Plasmon Excitations", Jpn.J.Appl.Phys. 34, L1467 (1995)

(3) A.Grund, A.Kaltbeitzel, A.Mathy, R.Schwarz, C.Bubeck, P.Vermehren and M.Hanack: "Resonant nonlinear Optical Properties of Spin-Cast Films of Soluble Oligomeric Brideged (Phthalocyanininate) ruthenium (II) complexes", J.Phys.Chem., 96, 7450 (1992)

(4) C.W.Tang: Appl.Phys.Lett., 48 (1986) 183

(5) M.M. Nicholson and F.A. Pizzarello: "Charge Transport in Oxidation Product of Lutetium Diphthalocyanine", J. Electrochem. soc. 126, 1490 (1979)

(6) S.Baker, G.G. Roberts, M.C.Petty: "Phthalocyanine Langmuir Blodgett-film gas detector" IEEE proceedings, 130, 260 (1983)

(7) M.J.Cook: "Langmuir-Blodgett films of Phthalocyanine", Int.J.electronics 76, 5, 727 (1994)

(8) S.A.VanSlyke, C.H.Chen and C.W.Tang:

Electroluminescence device with organic luminescent medium, U.S.Patent, 4, 720, 432 (1988)

(9) S.A.VanSlyke, C.H.Chen and C.W.Tang:

"Electroluminescence devices with improved stability", Appl. Phys. Lett., 69, 2160 (1996)

(10) A.Fujii, M.Yoshida, Y.Ohmori, K.Yoshino: "Two-Band Eelctroluminescent Emission in Organic Electroluminescent Diode with Phthalocyanine Film", Jpn.J.Appl.Phys., 35, L37 (1996)

(11) Fu-Ren fan and L. R. Faulkner: "Photovoltaic effects of metalfree and zinc phthalocyanines. I. dark electrical properties of rectifying cells", J. Chem. Phys. 69(7), 1, 3334 (1978)

(12) R.O.Loutfy and J.H.Sharp: "Photovoltaic properties of metal-free phthalocyanine. I.Al/ $\mathrm{H}_{2} \mathrm{Pc}$ Schottky barrier solar cells", J.Chem.Phys., 71(3), 1211 (1979)

(13) S.Okuyama, Y.Ito, T.Sugawara, K.Okuyama, and K.Matsushita: Appl.Phys.Lett., 71, 2877 (1997)

(14) S. Takeda: "Time dependence of current of plasma polymerized polystyrene thin film upon exposure to $\mathrm{NO}_{2}$ gas", Thin solid Films, 281-282, 539 (1996)

(15) E.Suzuki and Y.Hoshi: Journal of the Magnetics Society of Japan, Vol.21, Supplement, No.S2, 43 (1997)
新保 一成（正員） 1967 年 6 月 17 日生。1995 年 3 月新渴大学大学院自然科学研究科博士課 程修了。同年 4 月同大学大学院助手, 1997 年 4 月同大学工学部講師, 1998 年 2 月同 大学工学部助教授, 現在に至る。工学博士。 機能性有機薄膜の研究に従事。応用物理学 会, 日本液晶学会会員。

皆川 正寛 （非会員） 1974 年 12 月 29 日生。1998 年 3 月新潟大学工学部電気電子工学科卒 業。2000 年 3 月新渴大学大学院自然科学 研究科博士前期課程生産システム専攻修 了。同年 4 月沖データ（株）入社。現在, 日本精機株勤務。

高坂 秀明 （非会員）1976 年 7 月 9 日生。2000年 3

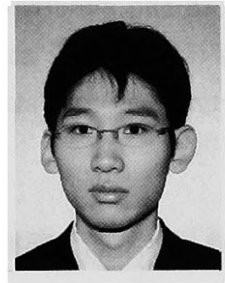
月新潟大学工学部電気電子工学科卒業。同 年 4 月新潟ダイヤモンド電機(株)入社。現在 に至る。

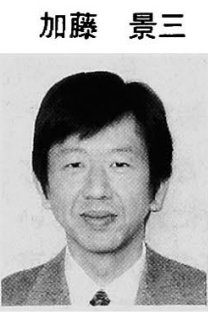

（正員） 1959 年 5 月 21 日生。1987 年 3 月東京工業大学大学院理工学研究科博士 課程電気・電子工学専攻修了。同年 4 月新 潟大学工学部助手。現在, 同大学院自然科 学研究科助教授。工学博士。電気電子材料, 機能性薄膜, 有機エレクトロニクスに関す る研究に従事。応用物理学会, 電子情報通 信学会,レーザー学会会貣。

金子双男（正員） 1950 年 4 月 1 日生。1974 年 3 月新渴大学大学院工学研究科修士課程修 了。同年 4 月東京工業大学助手。1981 年 4 月新渴大学工学部助教授, 1992 年 4 月同 教授, 現在に至る。この間, 1986 年 3 月 $\sim 1987$ 年 1 月 MIT客員研究員。工学博士。 電気電子材料, 有機薄膜の研究に従事。電 子情報通信学会, 応用物理学会, 日本液晶 学会会員。 